\title{
Do leaf-mining Nepticulidae occur in the natural but so threatened Andean Polylepis forests?
}

Jonas R. Stonis ${ }^{1}$,

Arūnas Diškus ${ }^{1}$,

Andrius Remeikis ${ }^{2}$,

Ole Karsholt ${ }^{3}$

${ }^{1,4}$ Lithuanian University

of Educational Sciences and

Baltic-American Biotaxonomy Institute,

Studentu St. 39,

LT-08106 Vilnius, Lithuania

${ }^{2}$ Institute of Ecology,

Nature Research Centre,

Akademijos St. 2,

LT-08412 Vilnius, Lithuania

${ }^{3}$ Zoological Museum,

Natural History Museum of Denmark,

Universitetsparken 15,

2100 København Ø, Denmark
Despite the fact that Polylepis forests constitute the natural but threatened vegetation in much of the high Andes and are very important for their ecological functions, no leaf-mining Nepticulidae (Insecta: Lepidoptera, Nepticuloidea) associated with Polylepis Ruiz \& Pav. as a host-plant have been recorded previously. In this paper, for the first time, we report on four discoveries of Polylepis-feeding Nepticulidae species in Ecuador and Peru. From the high Andes of Peru, we describe a new species Stigmella polylepiella Diškus \& Stonis, sp. nov., whose larvae throughout all instars are leaf-miners in leaves of Polylepis racemosa Ruiz \& Pav. and spin a unique shaped cocoon inside the leaf-mine. We also provide illustrations and short descriptions of male genitalia and leaf-mines of two other new Stigmella Schrank species, whose larvae are leaf-miners on Polylepis pauta Hieron. in Ecuador; these two taxa are documented but left unnamed because they are described from dissected developed pupae, not emerged adults. Additionally, we document leaf-mines of an unknown Nepticulidae taxon associated with Polylepis racemosa in the Peruvian Andes.

Key words: Polylepis, Nepticulidae, Stigmella Schrank, new species, leaf-mines, Peru, Ecuador

\section{INTRODUCTION}

Polylepis Ruiz \& Pav. is the only arborescent genus that occurs naturally at high elevations of the Andes (Harling, 1979; Kessler, 2002; Andean Páramo, 2016) (Figs. 1-6). After the glacial period the highlands of the Andes were open to colonization by Polylepis trees, and Polylepis forests constituted the natural vegetation in much of the high Andes (Clapperton, 1983; Hooghiemstra, Cleef, 1995; Fjeldså, Kessler, 1996).

\footnotetext{
* Corresponding author. E-mail: stonis@leu.lt
}

At altitudes between 3500 and $4000 \mathrm{~m}$, Pol$y$ lepis is the only resource of wood in a zone where other tree species are unable to grow (Fjeldså, Kessler, 1996). Some species of Polylepis even occur at an altitude of $4850 \mathrm{~m}$ (Braun, 1997). However, nowadays, mainly because of heavy deforestation, remnants of the high Andean forests, which have been conserved to present time, mostly either inhabit inaccessible steep slopes, deep canyons and ravines, places among rocks or the remaining patches of Polylepis forests are spread out in an open landscape but separated by huge areas of grass páramo (Ridbäck, 2008). 

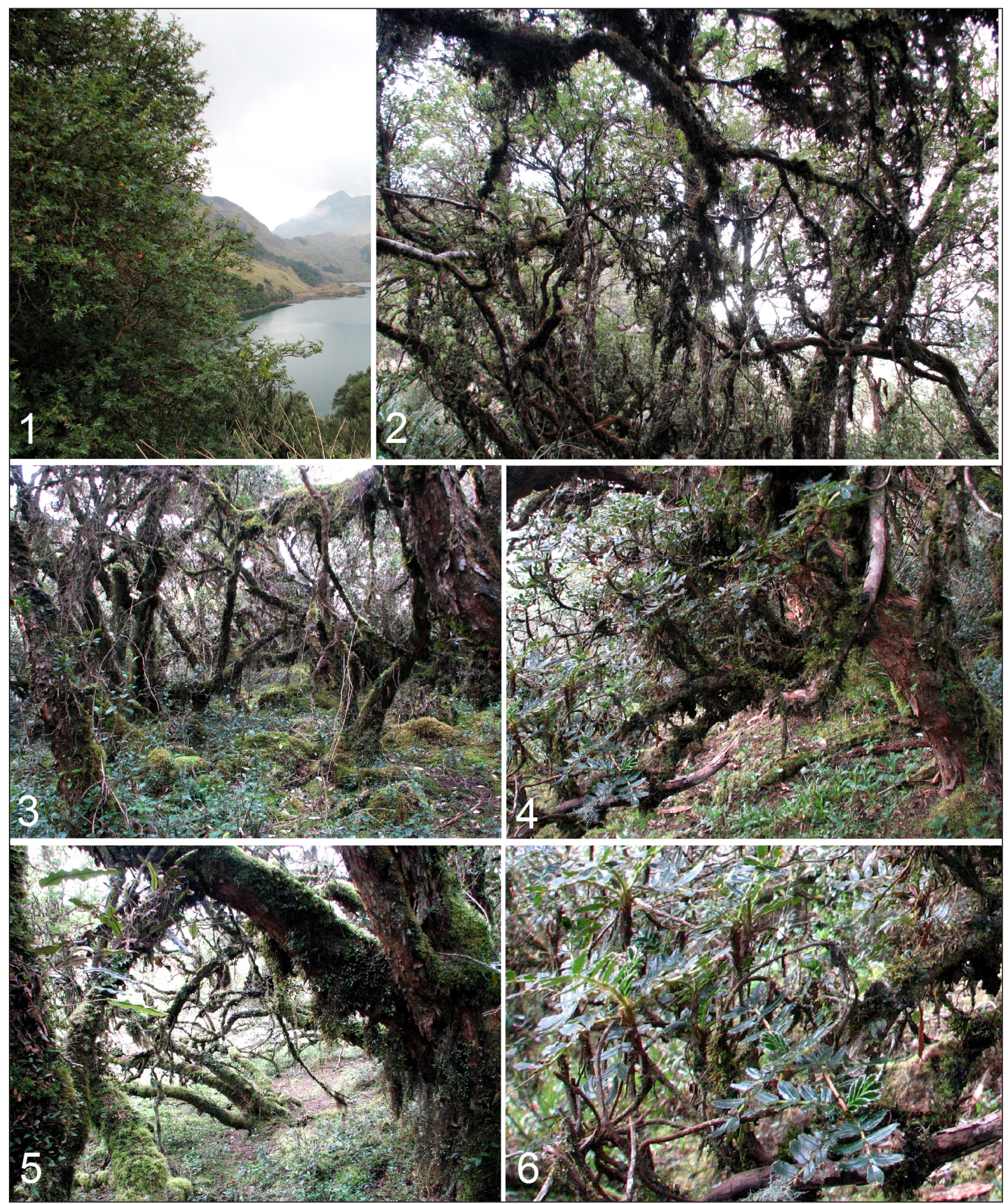

Figs. 1-6. Polylepis forest habitat, elevation about 3800 m, near Papallacta Pass, Napo Province, Ecuador

Within the family Rosaceae, i. e. the most common host-plant family of Nepticulidae in boreal regions, the genus Polylepis belongs to the tribe Sanguisorbeceae (the section Elongatae) (Simpson, 1986). It is interesting and phylogenetically important that the Andean endemic
Polylepis is most closely related to the shrubby genus Acaena which comprises about a hundred species mainly from New Zealand, Australia and South Africa. The wide geographical distribution of Acaena and its less specialized morphology suggest that it is a more primitive 
group and that Polylepis evolved from it (Simpson, 1986).

All currently recognized 20 (or 28) Polylepis species are endemic to the mid- and high-elevation areas of the equatorial and sub-equatorial Andes. All Polylepis species are bushes and trees of usually gnarled shape (Figs. 2, 3); only seldom they are trees with thick trunks and up to $20 \mathrm{~m}$ tall. The foliage is evergreen, with dense small leaves (Figs. 6, 8, 9, 35) and often large amounts of dead twigs hanging down from the underside of the canopy (Figs. 1-6). Polylepis is well adapted to the harsh climate in the high Andean mountains, having reduced flowers and leaves covered with woolly hairs (Fjeldså, Kessler, 1996). Polylepis species (as the tribe Sanguisorbae) are unique in the Rosaceae family in showing a tendency towards wind-polination - an useful evolutionary event in the adaptation to the highland where insects are much scarcer than in warmer climates.

The forests of Polylepis have a unique biological diversity (Fjeldså, Kessler, 1996). The trees harbour many species of epiphytic vascular plants, mosses and lichens, as well as animals. In a landscape dominated by open páramos, the forests give shelter, nesting sites, and food to many mammals and birds (Fjeldså, Kessler, 1996; Ridbäck, 2008). The Polylepis forests have some very important ecological functions. Forests of mountain ridges with persistent winddriven fog comb moisture out of the atmosphere. The forests may also act like a sponge, storing large amounts of water in the vegetation and in the organic soil that accumulate, releasing it gradually during the dry season (Fjeldså, Kessler, 1996).

Deforestation in the Andes has a long history: different ethnic groups inhabited the Andean highlands many generations before the Spanish conquistadors arrived (Ridbäck, 2008). Since humans entered this region the forests have been used as a source for building material and fuel (Fjeldså, Kessler, 1996). The practice to burn large areas to create farmlands or improve pastures in the Andes has reduced Polylepis forests to a few percentage of their original extent
(Ridbäck, 2008). Thus, human activities during several thousands of years have considerably changed the forests of Polylepis in the central Andes in Ecuador (Ridbäck, 2008) as well as in Peru or Bolivia. Moreover, these activities in the Andean páramo have increased drastically over the last two-three decades: there are strong scientific evidences that these activities have a dramatic impact on the integrity of the ecosystem (Cuesta, De Bievre, 2008).

Being native to the Andes (Hamen, Cleef, 1986; Kessler, 2002), Polylepis is of great value for reforestation programs. Considering its limited distribution in the Andean highlands, the Polylepis forests as such are worth conserving as a unique habitat and a harbour for very many species; they also protect the soil from erosion (Fjeldså, Kessler 1996).

No leaf-mining Nepticulidae associated with Polylepis have been recorded previously. During our fielwork conducted as part of Polylepis Expedition in 1987, and during other collecting in Peru (2008) and Ecuador (2001, 2005, and 2007), certain attention has been paid to Nepticulidae which would be associated with Polylepis as a host-plant. In this paper we report on the first discoveries of Polylepis-feeding Nepticulidae species in the high Andes of Ecuador and Peru (Fig. 7).

\section{MATERIALS AND METHODS}

Description or documentation of new species is based on material deposited in the collection of the Zoological Museum, University of Copenhagen, Denmark. Collecting methods and protocols for species identification and description are outlined in Puplesis (1994), Puplesis, Robinson (2000), and Puplesis, Diškus (2003). After maceration of the abdomen in $10 \% \mathrm{KOH}$ and subsequent cleaning, male genital capsules were removed from the abdomen and mounted ventral side uppermost. The phallus was removed and mounted in Euparal separately but on the same genitalia slide. Abdominal pelts (sometimes also genital capsules) were stained with Chlorazol Black (Direct Black 38/Azo Black) (see Stonis et al., 2014). 
Permanent slides were photographed and studied using a Leica DM2500 microscope and Leica DFC420 digital camera. The descriptive terminology of morphological structures follows Puplesis, Robinson (2000), except for the term "aedeagus", which is referred to here as "phallus", and the term "cilia", which is referred to here as "fringe".

Institutional abbreviations used in the text: ZMUC - Zoological Museum, University of Copenhagen, Denmark.

\section{RESULTS}

\section{Description of Stigmella polylepiella}

Diškus \& Stonis, sp. nov., on Polylepis racemosa from Peru

Type material. Holotype: ${ }^{\lambda}$, PERU, $60 \mathrm{~km}$ NW of Cuzco, Ollantaytambo, 13 $3^{\circ} 15^{\prime} 31^{\prime \prime}$, $72^{\circ} 15^{\prime} 54^{\prime \prime} \mathrm{W}$, elevation $2851 \mathrm{~m}$, mining larvae on Polylepis racemosa Ruiz \& Pav., 21.x.2008, field card no. 4948, A. Diškus, genitalia slide no. AD739 (ZMUC). Paratype: $1 \hat{O}^{\hat{O}}$, same label data as holotype, genitalia slide no. AD741 (ZMUC).

Diagnosis. The combination of the densely speckled forewing with some golden gloss and purple ireidescence, closely juxtaposed processes of gnathos, three-lobed uncus, and unique set of cornuti in the phallus distinguishes $S$. polylepiella sp. nov. from all other Stigmella species; the host-plant Polylepis racemosa (Rosaceae) also makes this species distinctive.

Male (Figs. 14-17). Forewing length about $2.6 \mathrm{~mm}$; wingspan 5.7-5.8 mm. Head: palpi cream to greyish cream; frontal tuft ferruginous; collar and scape cream; antenna distinctly longer than half the length of forewing; flagellum with 44-47 segments, dark grey, glossy. Thorax, tegula and forewing densely speckled

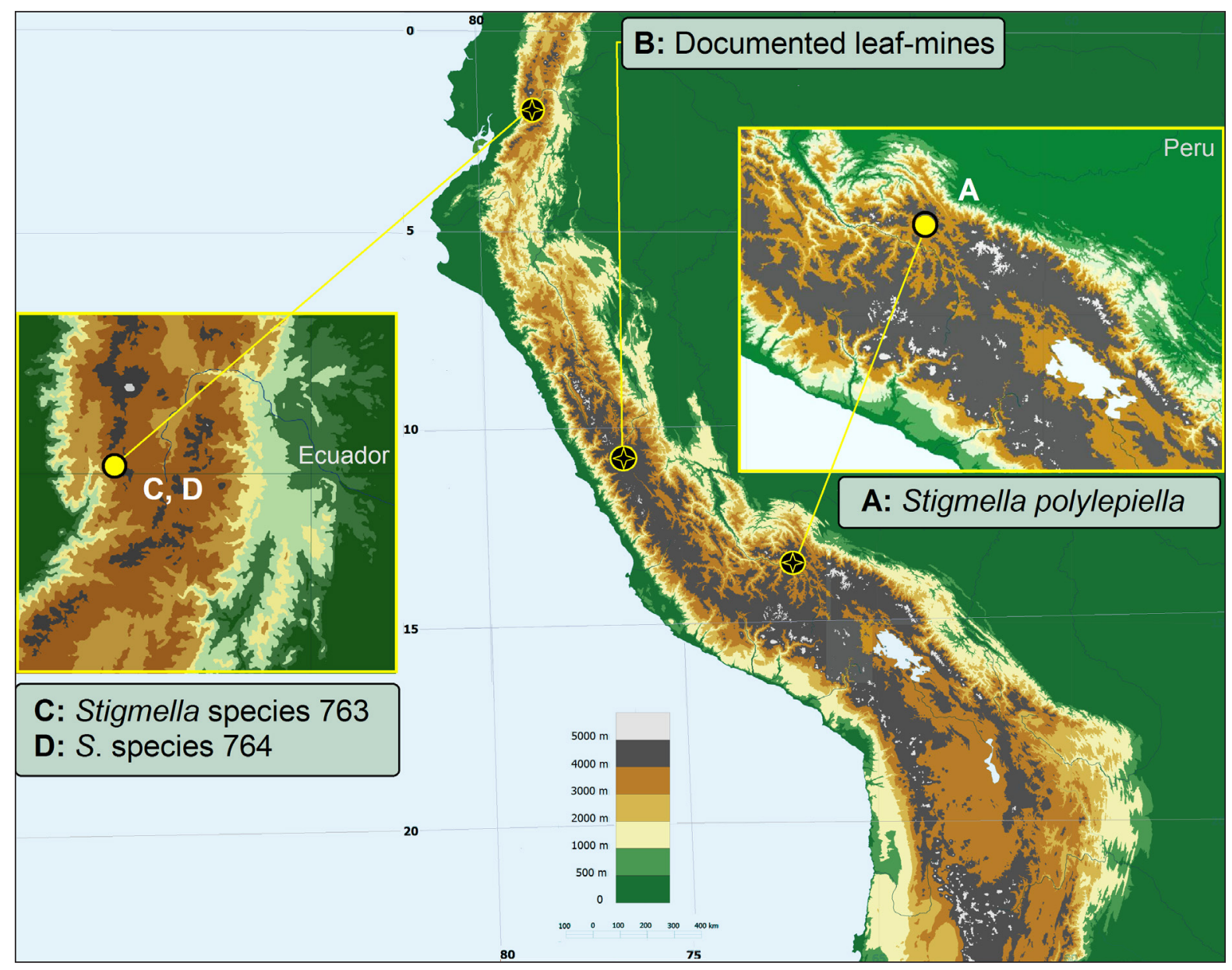

Fig. 7. Map with currently known Nepticulidae records on Polylepis 


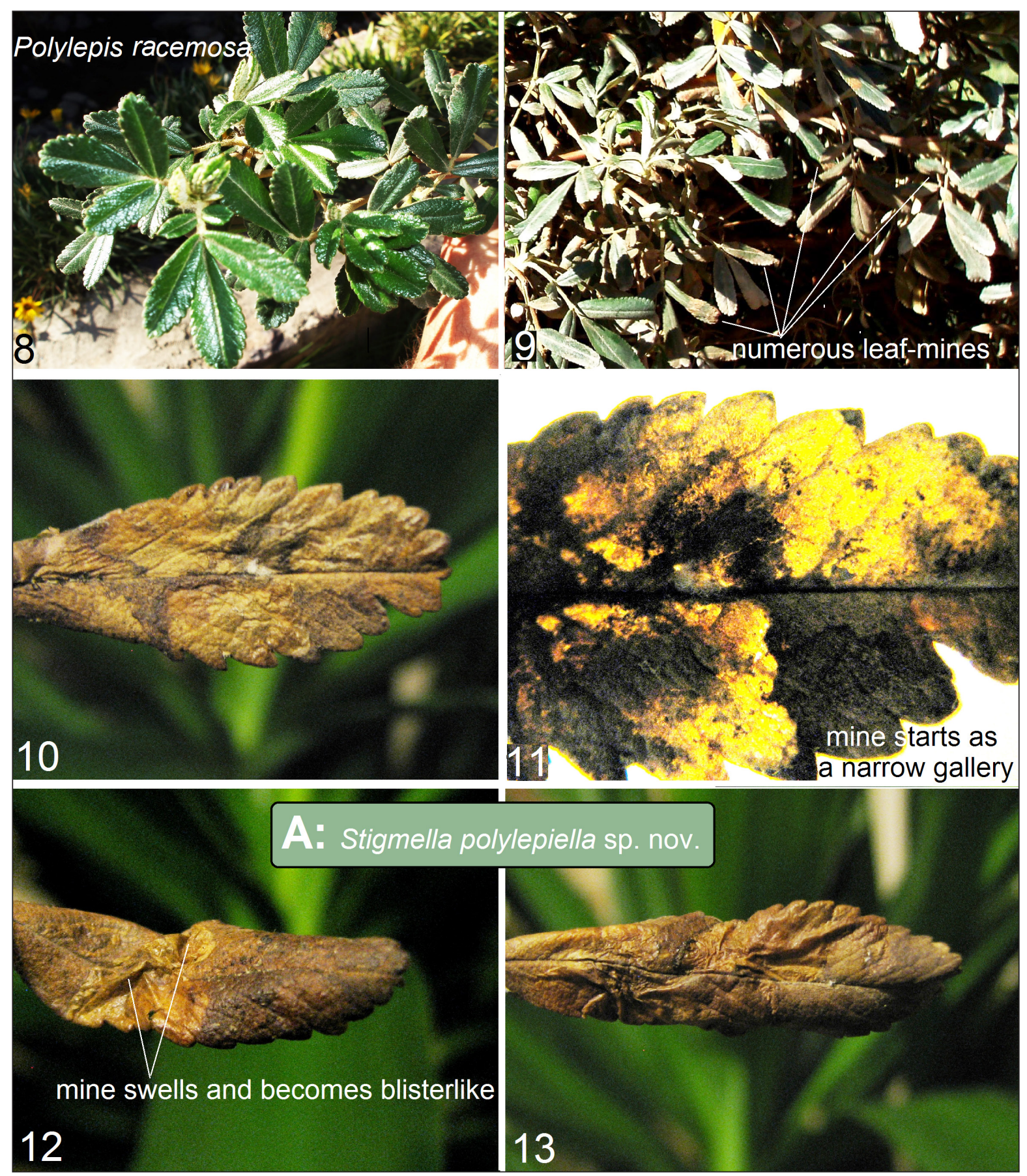

Figs. 8-13. Bionomics of Stigmella polylepiella Diškus \& Stonis, sp. nov. 8, 9, host-plant Polylepis racemosa Ruiz \& Pav., Rosaceae (with an infested bush in photograph 9); 10-13, leaf-mines, Ollantaytambo, $60 \mathrm{~km}$ NW of Cuzco, Peru, $13^{\circ} 15^{\prime} 31^{\prime \prime S}, 72^{\circ} 15^{\prime} 54^{\prime \prime W}$, at elevation about $2850 \mathrm{~m}$

with dark grey scales with coppery golden gloss and purple iridescence. Forewing without fascia; fringe dark grey; underside of forewing fuscous with little purple iridescence; no spots or androconia. Hindwing grey on upper side and underside; its fringe dark grey. Legs grey, sil- very shining, darkened with dark grey on upper side. Abdomen dark grey to fuscous on upper side, grey cream on underside.

Female. Unknown.

Male genitalia (Figs. 22-26). Capsule longer $(235-240 \mu \mathrm{m})$ than wide $(130 \mu \mathrm{m})$. Uncus very 


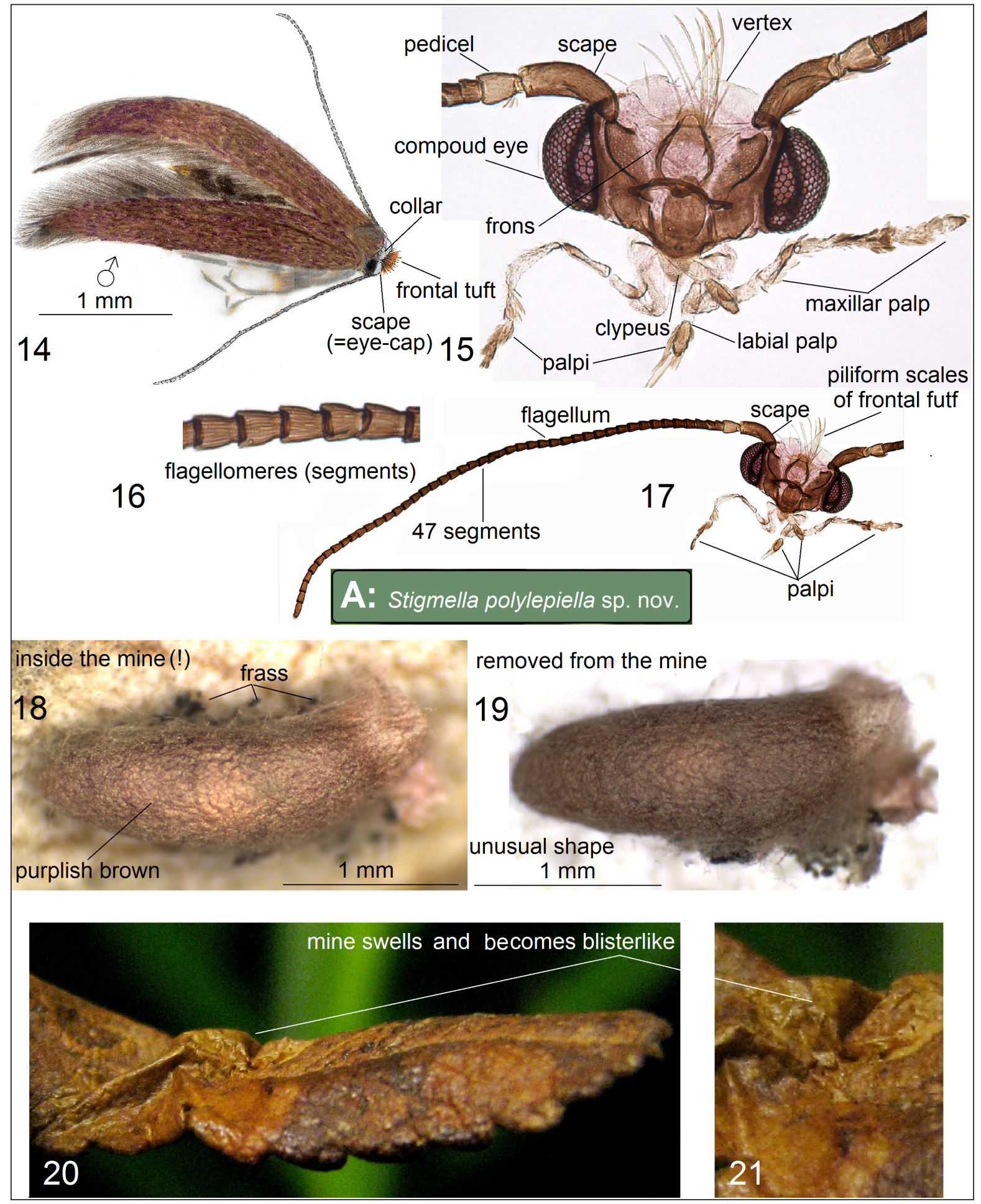

Figs. 14-21. Stigmella polylepiella Diškus \& Stonis, sp. nov. 14, holotype, male adult; 15, same, descaled head; 16, same, fragment of descaled flagellum; 17, same, descaled head with flagellum; 18, 19, cocoon; 20,21 , leaf-mine with cocoon inside

wide, with three very short caudal lobes. Gnathos with two juxta-posed caudal processes, narrow central plate and extended corners. Valva $145-150 \mu \mathrm{m}$ long, 35-45 $\mu \mathrm{m}$ wide, with two apical processes; inner lobe slightly bulged; transtilla without sublateral processes. Juxta membranous, indistinct or absent. Vinculum with triangular lateral lobes. Phallus (Figs. 24, 


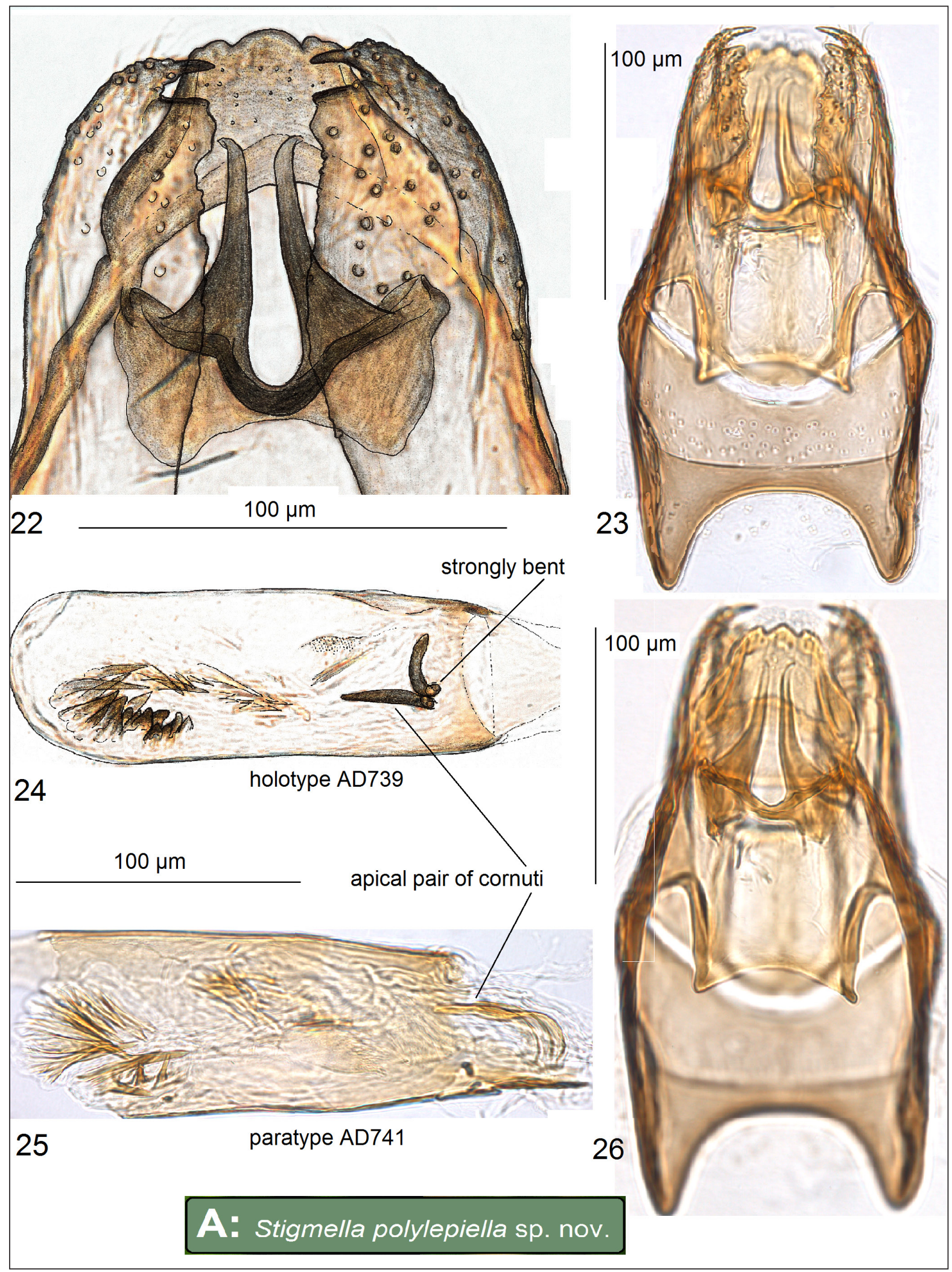

Figs. 22-26. Male genitalia of Stigmella polylepiella Diškus \& Stonis, sp. nov. 22, caudal part of capsule, holotype, genitalia slide AD739; 23, capsule with phallus removed, paratype, genitalia slide AD741; 24, phallus, holotype, genitalia slide AD739; 25, same, paratype, genitalia slide AD741;26, dorsal view of capsule, paratype, genitalia slide AD741 (ZMUC) 
25) 190-195 $\mu \mathrm{m}$ long, 50-65 $\mu \mathrm{m}$ wide; vesica with unique set of cornuti; two apical cornuti strongly bent (well visible in slide AD741, Fig. 25; little visible but bent in slide AD739, Fig. 24).

Bionomics (Figs. 8-13, 20, 21). Larvae mine in leaves in October. Host-plant: Polylepis racemosa Ruiz \& Pav. (Rosaceae) (Figs. 8, 9). Egg beige cream, mat (lustreless), oval-shaped, flattened dorso-ventrally, attached (not glued) on the leaf under side. Leaf-mine starts as a narrow gallery filled with black frass; later it develops abruptly to a large blotch with frass irregularly scattered but most of it remains accumulated in basal part of the blotch (Figs. 10, 11). Larva spins its cocoon inside the mine; the mine swells and becomes blisterlike at this stage (Figs. 12, 13, 20, 21). Cocoon purplish brown to purplish dark brown; shape of the cocoon unusual, narrow; length 2.0$2.4 \mathrm{~mm}$, maximal width $0.8-0.83 \mathrm{~mm}$. Exit slit on upper side of the leaf. After the 'Formula of Evaluation of Abundance and Occurrence of Leaf-miners' (see Diškus, Stonis 2012: 52-54), Stigmella polylepiella is extremely abundant in the type locality: a mass mining of the new species were observed (sometime with a few leaf-mines on a single leaf); more than 300 leaf-mines with larvae were collected at a single site in Ollantaytambo, Peru (Fig. 9).

Distribution (Fig. 7). This species occurs in the Andes (Peru: NW of Cuzco) at an altitude of about $2850 \mathrm{~m}$.

Etymology. The species is named after the host-plant genus Polylepis Ruiz \& Pav.

\section{Documentation of Stigmella species 763 on Polylepis pauta from Ecuador}

Material examined. $1 \delta^{\hat{T}}$ [dissected from completely developed pupa within the pupal case], ECUADOR: Chimborazo Province, ca. $30 \mathrm{~km}$ NE Pallatanga, $1^{\circ} 52^{\prime} 41^{\prime \prime} \mathrm{S}, 78^{\circ} 54^{\prime} 11^{\prime \prime} \mathrm{W}$, elevation about $3325-3400 \mathrm{~m}, 8$ mining larvae on Polylepis pauta Hieron. (Rosaceae), 24.i.2005, field card 4829, leg. A. Diškus \& J. R. Stonis, genitalia slide no. AD763 (ZMUC); 1 mining larva on Polylepis pauta, same locality, 21.ii.2007, field card 4881, leg. A. Diškus.
Diagnosis. The combination of the unique set of cornuti in the phallus, specific shape of uncus, very short lateral lobes of vinculum, and two apical processes of valva distinguishes S. species 763 from all other Stigmella species; the host-plant Polylepis pauta Hieron. (Rosaceae) also makes this species distinctive.

Male. Unknown (the species was documented from dissected, completely developed pupa within the pupal case).

\section{Female. Unknown.}

Male genitalia (Figs. 38-40). Capsule longer $(260 \mu \mathrm{m})$ than wide $(180 \mu \mathrm{m})$. Uncus wide, with short caudal lobes. Gnathos with two rather short caudal processes, wide central plate and extended corners. Valva $150 \mu \mathrm{m}$ long, 70-80 $\mu \mathrm{m}$ wide, with two distinct apical processes; transtilla with very small sublateral processes. Juxta membranous (indistinct) or absent. Vinculum with very small rounded lateral lobes. Phallus (Fig. 40) $180 \mu \mathrm{m}$ long, 90-95 $\mu \mathrm{m}$ wide; vesica with the unique set of cornuti: five strongly thickened horn-like cornuti and numerous, little thickened spine-like cornuti.

Bionomics (Figs. 33-37). Larvae mine in leaves in January. Host-plant: Polylepis pauta Hieron. (Rosaceae) (Fig. 35). Egg unknown. Larva brownish yellow (see Remarks on Stigmella species 764). Leaf-mine starts as a narrow gallery almost entirely filled with blackbrown frass; later gallery develops abruptly to a large blotch with black-brown frass accumulated (irregularly scattered) in basal part of the blotch (see Remarks on Stigmella species 764) (Fig. 36). Larva spins its cocoon outside the mine; the mine turns brown when older or vacant, only little transparent. Cocoon yellowish brown, oval shaped. Exit slit on upper side of the leaf.

Distribution (Fig. 7). Known from a single locality in the Equatorial Andes (Chimborazo Province, Ecuador). The habitat is montane moist mixed forest with Polylepis pauta (Figs. 33, 34).

Remarks. This very remarkable and undoubtedly new species is documented but not named pending the availability of additional 


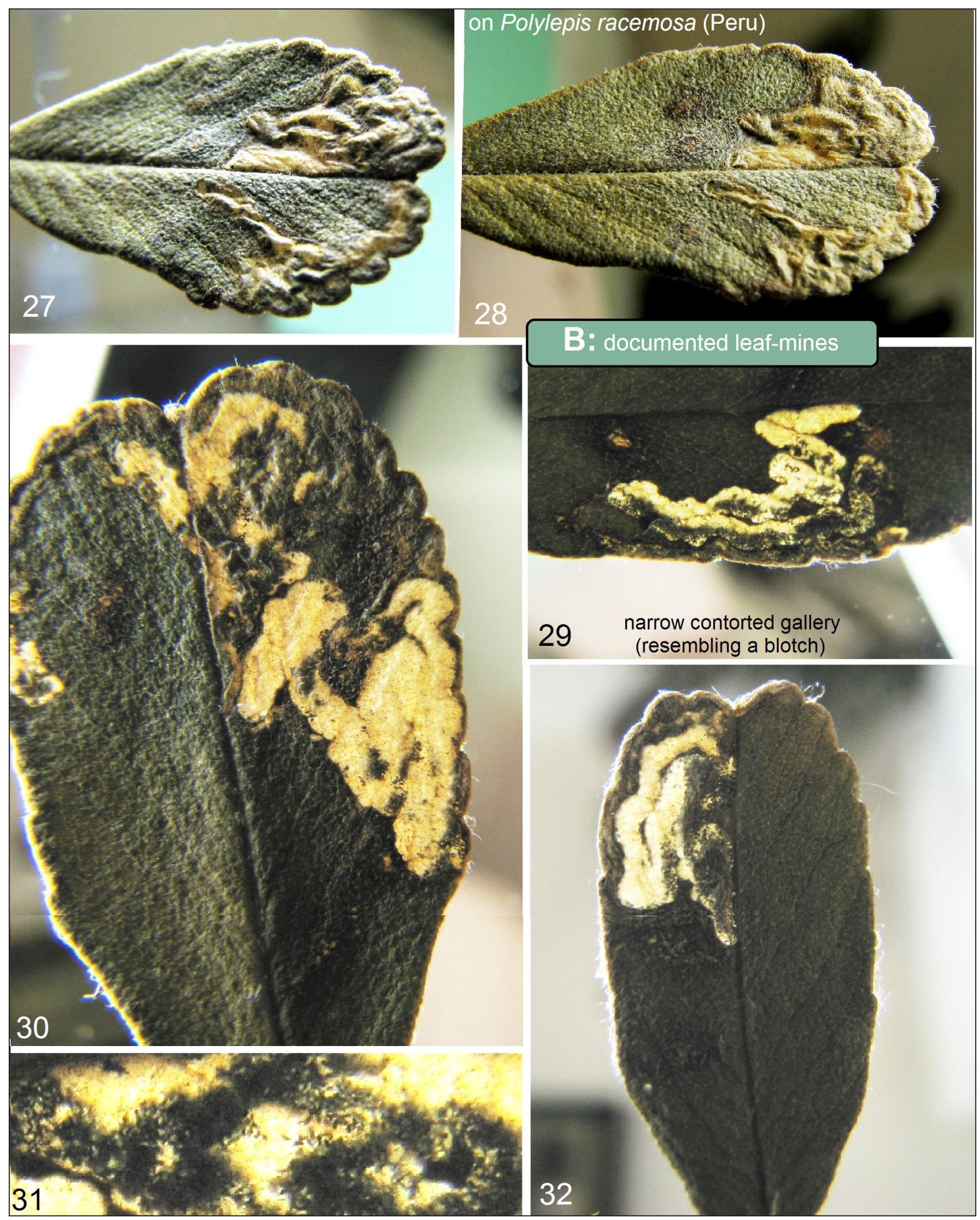

Figs. 27-32. Documentation of leaf-mines on Polylepis racemosa Ruiz Lopez \& Pavon (Rosaceae), Peru: Junin Province, Ondores (collecting site "7" by O. Karsholt), elevation 4100 m, leg. O. Karsholt / Polylepis Expedition of 1987 (ZMUC)

material. The documented but unnamed taxon is distinguished by the number of the corresponding genitalia slide, i. e., Stigmella species
763 is a taxon exemplified by the pupa specimen from which male genitalia slide AD763 (ZMUC collection) was made. 


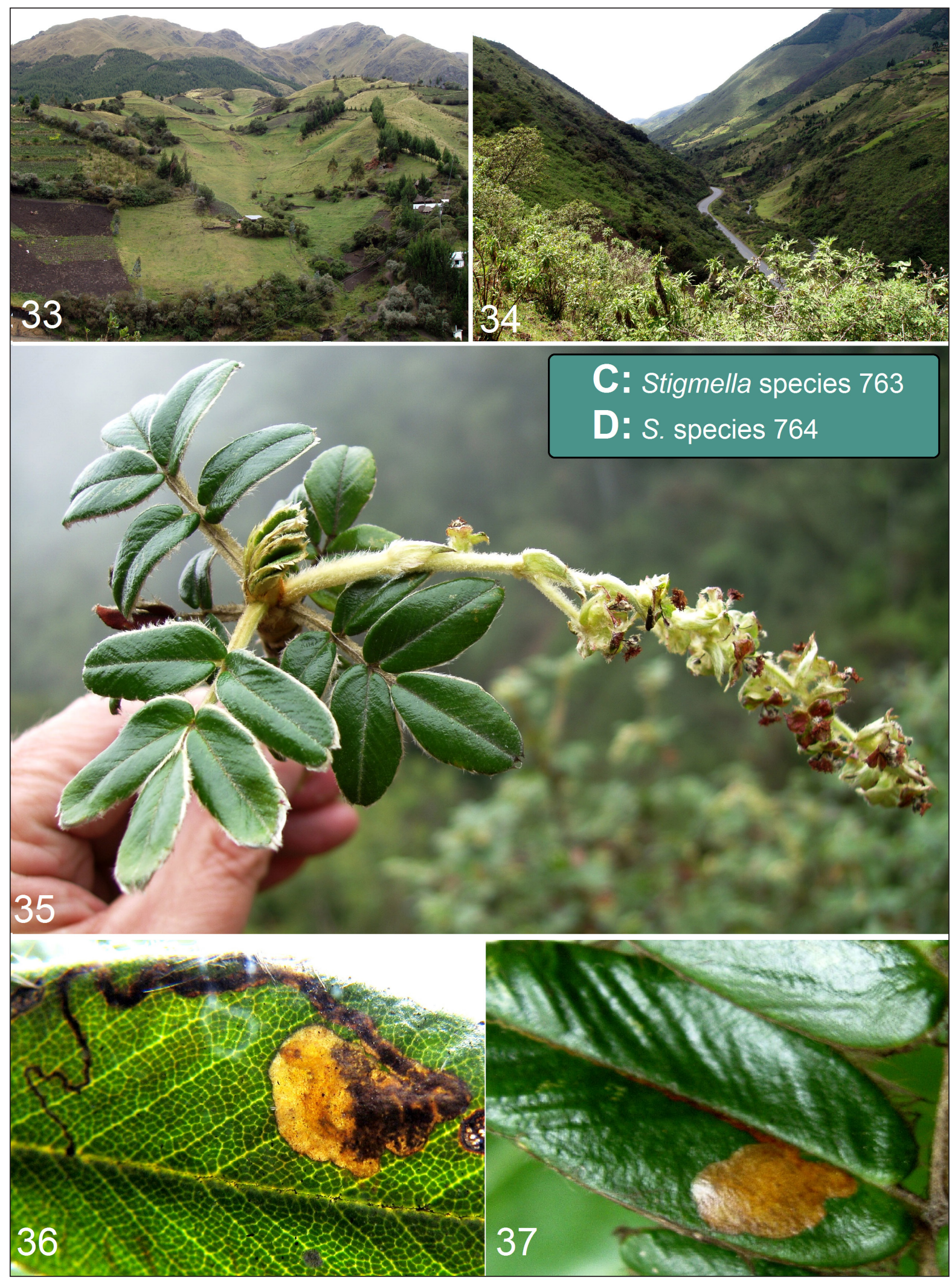

Figs. 33-37. Bionomics of Stigmella species 763 and species 764. 33, 34, habitat, montane moist forest with Polylepis pauta, Pangor Canyon, 30 km NE Pallatanga, Ecuador, 1'52'41”'S, 78 $54^{\prime} 11^{\prime \prime} \mathrm{W}$, elevation $3025 \mathrm{~m}$; 35, host-plant Polylepis pauta Hieron.; 36, 37, leaf-mines from which two different new species on Polylepis (Stigmella species 763 and species 764) were reared (see Remarks on Stigmella species 764) 


\section{Documentation of Stigmella species 764 on Polylepis pauta from Ecuador}

Material examined. $1 \delta$ [dissected from completely developed pupa within the pupal case], ECUADOR: Chimborazo Province, ca. $30 \mathrm{~km}$ NE Pallatanga, $1^{\circ} 52^{\prime} 41^{\prime \prime}$, 78 54'11"W, elevation about 3325-3400 m, 1 mining larva on Polylepis pauta Hieron. (Rosaceae), 24.i.2005, field card 4829, leg. A. Diškus \& J. R. Stonis, genitalia slide no. AD764 (ZMUC).

Diagnosis. The combination of the membranous phallus with small group of spine-like cornuti, specific shape of widely lobate uncus, extremely very short ventral plate of vinculum with very short lateral lobes, membranous transtilla, and large lobate central plate of gnathos distinguishes $S$. species 764 from all other Stigmella species; the host-plant Polylepis pauta Hieron. (Rosaceae) also makes this species distinctive.

Male. Unknown (the species was documented from dissected, completely developed pupa within the pupal case).

Female. Unknown.

Male genitalia (Figs. 41-43). Capsule slightly longer $(250 \mu \mathrm{m})$ than wide $(235 \mu \mathrm{m})$. Uncus very wide, divided into two caudal lobes. Gnathos with two slender and long caudal processes and wide lobate central plate. Valva 200-205 $\mu \mathrm{m}$ long, 65-75 $\mu \mathrm{m}$ wide (see Remarks), without distinct apical processes; transtilla membranous, without sublateral processes. Juxta invisible or absent. Vinculum with extremely very short ventral plate and very small lateral lobes. Phallus (Fig. 43) not thickened, almost membranous, $175 \mu \mathrm{m}$ long, $125 \mu \mathrm{m}$ wide; vesica with a small group of little thickened spine-like cornuti.

Bionomics (Figs. 33-37). Larvae mine in leaves in January. Host-plant: Polylepis pauta Hieron. (Rosaceae) (Fig. 35). Egg unknown. Leaf-mine as a gallery which develops to a large blotch (see Remarks). Larva spins its cocoon outside the mine. Cocoon yellowish brown, oval-shaped. Exit slit on upper side of the leaf. Otherwise unknown.

Distribution (Fig. 7). Known from a single locality in the Equatorial Andes (Chimbo- razo Province, Ecuador). The habitat is montane moist mixed forest with Polylepis pauta (Figs. 33, 34).

Remarks. There are certain doubts about morphology of the leaf-mine of the species. Leaf-mine samples should be collected very carefully: samples might easily be mixed up if two different species mine at the same hostplant at the same time and produce closely similar or variable leaf-mines. Nevertheless, during our investigation there were instances of rearing adults of two different species from the same sample as in case of Stigmella species 763 and $S$. species 764 . Therefore, now it is rather difficult to described precisely and attribute correctly the similar leaf-mines to the reared different species from the mixed sample.

In contradiction to A. Diškus, who made the dissection, it was suspected by J. R. Stonis and A. Remeikis that the valva of Stigmella species 764 (Fig. 42) possesses two wide but overlapped lobes: ventral and dorsal. However, in the permanent mount no. AD764 it is too difficult to see either the valva simple or widely bilobed.

This very remarkable and undoubtedly new species is documented but not named pending the availability of additional material. The documented but unnamed taxon is distinguished by the number of the corresponding genitalia slide, i.e., Stigmella species 764 is a taxon exemplified by the pupa specimen from which male genitalia slide AD764 (ZMUC collection) was made.

\section{Documentation of leaf-mines of Nepticuli- dae on Polylepis racemosa from Peru}

Leaf-mine samples examined. 12 leaf-mines (no larvae or adults), PERU: Junin Province, Ondores (collecting site " 7 " by O. Karsholt), elevation 4100 m, 29.i.-5.ii.1987, leg. O. Karsholt / Polylepis Expedition (ZMUC).

Documentation. Mines in leaves (Figs. 27, 28). Host-plant: Polylepis racemosa Ruiz \& Pav. (Rosaceae). Egg glossy white, oval shaped (not flattened!), attached (but not glued) to the highly hairy leaf underside. Larva mine in January and February (judging on observed vacant 


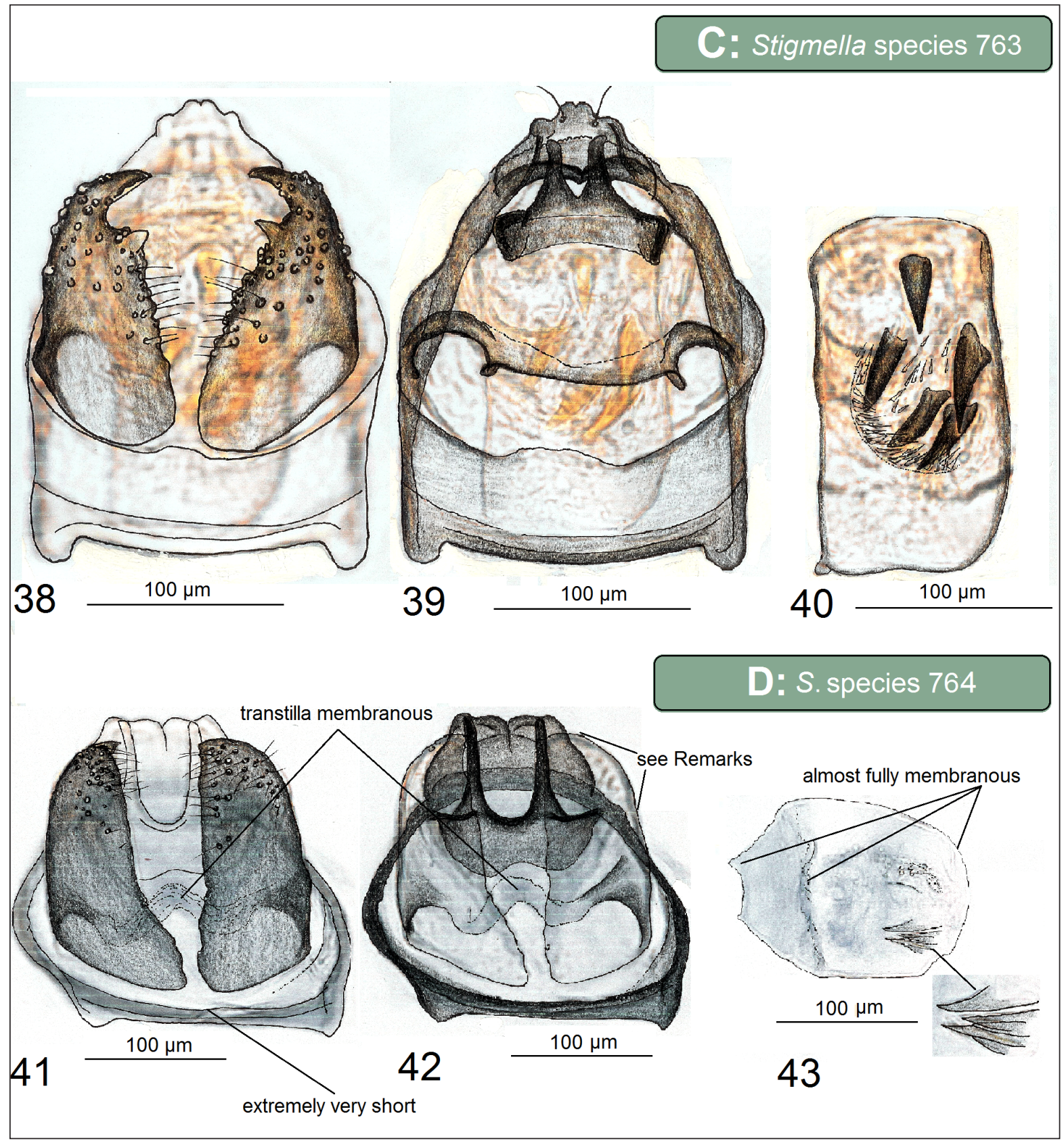

Figs. 38-43. Male genitalia of new species on Polylepis from Ecuador. 38, Stigmella species 763, genitalia slide AD763, valvae; 39, same, dorsal view of capsule; 40, same, phallus; 41, Stigmella species 764, genitalia slide AD764, valvae; 42, same, dorsal view of capsule; 43, same, phallus (ZMUC)

leaf-mines), also possibly in early April. Leafmine as a gradually widening but strongly contorted gallery (therefore it may resemble a blotch) (Figs. 29, 30, 32). Black frass forms an interrupted or continuous central line filling most of the gallery; the distal part of the gallery with wide areas without frass. Larval exit slit on upper side of the leaf.
It occurs in the high Andes NE of Lima (Peru) at an altitude of about $4100 \mathrm{~m}$.

Remarks. The documented leaf-mines on Polylepis racemosa belong to an unknown Nepticulidae species (possibly belonging to the genus Stigmella Schrank). However, no pupae or adults are available for further discussion and description. 


\section{DISCUSSION}

1. Leaf-mining Nepticulidae species are associated with at least two species of Polylepis as a host-plant (including Polylepis racemosa and P. pauta) occurring in the high Andes of Peru and Ecuador and belong to the genus Stigmella Schrank, the biggest and worldwide widespread generic taxa within the family Nepticulidae. All discovered Nepticulidae taxa are new, but only Stigmella polylepiella sp. nov. was described and named; other taxa were documented but left unamed pending additional material (currently, only dissected pupae, not adults, are available).

2. Stigmella polylepiella sp. nov. was observed as a highly abundant species with mass mining of Polylepis racemosa in the Andes NW of Cuzco (literally infesting the host-plant), while the Ecuadorian Stigmella species 763 and S. species 764 on Polylepis pauta are probably rare because so far only a few leaf-mines were recorded. Mining seasons of Polylepis-feeding species occur in January (Stigmella species 763 and S. species 764) and in October (Stigmella polylepiella sp. nov.).

3. There usually is no difficulty with rearing adult Nepticulidae from mining larvae using the proper methods as described in Diškus, Stonis (2012). But in the case of Polylepis-feeding species occurring in the high Andes (páramo or puna), the rearing of adults from larvae can be a great challenge. During our fieldwork, even in the case of exceptionally large samples of up to few hundreds of mining larvae (Stigmella polylepiella sp. nov.), only a couple larvae developed to mature pupae and emerged. In case of Stigmella species 763 and S. species 764 , pupae stopped their development and died within the pupal case. Causes of this phenomenon (Stonis et al., 2016) are unknown and certainly not related to parasitoids.

4. In contradiction to expectations, the first discoveries of leaf-mining Nepticulidae on Polylepis revealed that species feeding on Polylepis are not closely related but indicate unexpectedly great morphological diversity (more than usual in comparison to species feeding on the most of other host-plant genera in South America, see Stonis et al., in prep.), and represent highly distinctive taxa among all known Stigmella worldwide. Apriori we can assume that these species (particularly Stigmella species 764) are rather a result of older evolutionary events than the recent speciation so commonly known in the Andean fauna (including the fauna of Nepticulidae).

\section{ACKNOWLEDGEMENTS}

We are indebted to the late Prof. Niels P. Kristensen (ZMUC) for the initial stimulus for the Neotropical project and his generous support during its course. The authors also greatly thank Prof. Dr. Jon Fjeldså (the leader of Polylepis Expeditions, ZMUC) for supporting Ole Karsholt during his fieldwork in Peru in 1987 and his worldwide known, highly useful publications on unique biodiversity of the Andean Polylepis forests and their ecological importance.

This study was supported by the Research Foundation of the Lithuanian University of Educational Sciences (2015/2016). Andrius Remeikis is grateful to the Baltic-American Biotaxonomy Institute for the research stipend in 2015-early 2016 and for the research stipend in 2016 from the Research Foundation of the Research Council of Lithuania.

Received 12 April 2016 Accepted 22 June 2016

\section{References}

1. Andean Páramo. 2016. Available from: http:// www.biome-explorer.net/Paramo/Andean\%20Paramo.html (accessed 30.3.2016)

2. Braun G. The use of digital methods in assessing forest patterns in an Andean environment: the Polylepis example. Mt Res Dev. 1997; 17: 253-62.

3. Clapperton CM. The glaciation of the Andes. Quat Sci Rev. 1983; 2: 83-155. 
4. Cuesta CF, De Bievre B. Páramo or northern Andes (Venezuela, Colombia, Ecuador, northern Perú). In: Michelson A, editor. Temperate grasslands of South America. The world temperate grasslands conservation initiative workshop. Hohhot (China); 2008. p. 3-11.

5. Diškus A, Stonis JR. Leaf-mining insects of Lithuania. The Nepticulidae (Lepidoptera): taxonomy, chorological composition and trophic relationships [monograph]. Kaunas: Lututè Publishers; 2012. 220 p. Lithuanian.

6. Fjeldså J, Kessler M. Conserving the biological diversity of Polylepis woodlands of the highland of Peru and Bolivia: a contribution to sustainable natural resource management in the Andes. Copenhagen: Nordeco; 1996. $250 \mathrm{p}$.

7. Harling G. The vegetation types of Ecuador a brief survey. In: Larsen K, Holm-Nielsen LB, editors. Tropical botany. London: Academic Press; 1979. p 165-74.

8. Hooghiemstra H, Cleef AM. Pleistocene climatic change and environmental and generic dynamics in the North Andean montane forest and paramo. In: Churchill SP, Balslev $\mathrm{H}$, Forero E, Luteyn JL, editors. Biodiversity and conservation of neotropical Montane forests. New York: The New York Botanical Garden; 1995. p. 35-49.

9. Hooghiemstra H, Hoorn MC, Helmens KF, Wyninga VM, Ran ETHH, Cleef AM, Kuhry P, van der Hammen T. Miocene to Pleistocene geo-ecological development of Amazonian and Andean Colombia: tectonics, basin development, migration, evolution and climatic change. In: Herngreen JFW, editor. Volume of Abstracts 4th European Palaeobotanical and Palynological Conference. Heerlen: Stichting Geologie en Paleontologie; 1994. p. 39-43. http://doi.org/10.11646/zootaxa.4061.2.2

10. Johansson R, Nielsen ES, Nieukerken EJ van, Gustafsson B. The Nepticulidae and Opostegidae (Lepidoptera) of North West Europe. Fauna Entomol Scand. 1990; 23(1/2): 1-739.

11. Kessler M. The elevational gradient of Andean plant endemism: varying influences of taxon- specific traits and topography at different taxonomic levels. J Biogeogr. 2002; 29: 1159-65.

12. Puplesis R. The Nepticulidae of Eastern Europe and Asia: western, central and eastern parts. Leiden: Backhuys Publishers; 1994. 291 p.

13. Puplesis R, Diškus A. The Nepticuloidea \& Tischerioidea (Lepidoptera) - a global review, with strategic regional revisions. Kaunas: Lututè Publishers; 2003. 512 p.

14. Puplesis R, Diškus A, Robinson GS. New Neotropical Nepticulidae (Lepidoptera) from the western Amazonian rainforest and the Andes of Ecuador. Bull Nat Hist Mus Entomol. 2002a; 71(1): 19-58.

15. Puplesis R, Diškus A, Robinson GS, Onore G. A review and checklist of the Neotropical Nepticulidae (Lepidoptera). Bull Nat Hist Mus Entomol. 2002b; 71(1): 59-76. http://dx.doi. org/10.1017/S0968045402000032

16. Puplesis R, Robinson GS. A review of the Central and South American Nepticulidae (Lepidoptera) with special reference to Belize. Bull Nat Hist Mus Entomol. 2000; 69(1): 3-114.

17. Ridbäck U. A floristic study of Polylepis forest fragments in the central Andes of Ecuador. Examensarbete i biologi. Visby: Högskolan på Gotland; 2008. 25 p.

18. Simpson BB. Speciation and specialization of Polylepis in the Andes. In: Vuilleumier F, Monasterio $\mathrm{M}$, editors. High altitude tropical biogeography. Oxford: Oxford University Press; 1986. p. 304-316.

19. Stonis JR, Diškus A, Remeikis A. The first description of the leaf-mining Nepticulidae (Lepidoptera) feeding on the South American plant genus Liabum, Asteraceae. Zootaxa. 2015; 4040(5): 576-82.

20. Stonis JR, Diškus A, Remeikis A, Cumbicus Torres N. First description of leaf-mining Nepticulidae and Tischeriidae (Insecta, Lepidoptera) feeding on the Chilean endemic plant genus Podanthus Lag. (Asteraceae). Zootaxa. 2016; 4061(2): 119-30.

21. Stonis JR, Diškus A, Remeikis A, Davis DR, Solis MA, Cumbicus Torres N. The first record 
of Baccharis L. (Asteraceae) as a host-plant genus for Nepticulidae (Lepidoptera), with description of new Stigmella species from South America. Zootaxa. 2016; 4136 (1): 101128. Available from: http://doi.org/10.11646/ zootaxa.4136.1.4

22. Stonis JR, Diškus A, Remeikis A, Navickaitè A. Study methods of Nepticulidae: micro-mounts of genitalia structures. In: Stonis JR, Hill SR, Diškus A, Auškalnis T, editors. Selected abstracts and papers of the First Baltic International Conference on Field Entomology and Faunistics. Vilnius: Edukologija Publishers; 2014. p. 32-5.

23. Stonis JR, Diškus A, Remeikis A, Navickaite A, Rocienè A. Description of new species of oak leaf-miners (Lepidoptera: Nepticulidae), with notes on the species groups of Stigmella Schrank associated with Quercus as a hostplant. Zootaxa. 2013; 3737(3): 201-22.

24. Stonis JR, Diškus A, Remeikis A, Schuster J. First discovery of Quercus feeding Nepticulidae (Lepidoptera) in Central America. Zootaxa. 2013; 3737(1): 1-23.

25. van der Hammen T, Cleef AM. Development of the high Andean Páramo flora and vegetation. In: Vuilleumier F, Monasterio M, editors. High altitude tropical biogeography. Oxford: Oxford University Press; 1986. p. 153-201.

\section{Jonas Rimantas Stonis, Arūnas Diškus,} Andrius Remeikis, Ole Karsholt

\section{AR LAPUS MINUOJANTYS MAŽIEJI \\ GAUBTAGALVIAI (NEPTICULIDAE) GYVENA NATŪRALIUOSE, BET NYKSTANČIUOSE ANDŲ KALNŲ POLYLEPIS MIŠKUOSE?}

\section{Santrauka}

Aukštujų Andų kalnų Polylepis miškai yra natūrali, ekologijos ir biologinès ịvairovès požiūriu itin svarbi, bet žmogaus smarkiai naikinama buveinè. Iki šiol nieko nebuvo žinoma apie mažuosius gaubtagalvius (Lepidoptera, Nepticulidae, Nepticuloidea), kurie būtų mitybiniais ryšiais susieti su Polylepis Ruiz \& Pav. genties medžiais. Šiame straipsnyje pateikiami tyrimų rezultatai pirmą kartą byloja apie Ekvadore ir Peru Polylepis lapus minuojančius Nepticulidae. Aprašoma nauja mokslui rūšis - Stigmella polylepiella Diškus \& Stonis, sp. nov., kuri aptikta aukštuosiuose Andų kalnuose Peru ir kurios visų ūgių vikšrai yra Polylepis racemosa Ruiz \& Pav. lapų minuotojai. Be išskirtinių morfologinių struktūrų ypatybių, šiai naujai rūšiai būdingi ir neiprastos formos kokonai, susidarantys minos viduje, o ne miško pakloteje. Taip pat aprašomos dar dvi kitos Stigmella Schrank genties rūšys, aptiktos Ekvadore; jų vikšrai minuoja Polylepis pauta Hieron. lapus. Nors abi šios rūšys yra naujos, straipsnyje joms nebuvo suteikti lotyniški pavadinimai tikintis daugiau tyrimų ir kolekcinès medžiagos ateityje; šiuo metu neịvardytų rūšių (Stigmella species 763 ir S. species 764) yra išaiškintos ir preparuotos tik suaugusios lèliukès, o ne patys suaugèliai (imagai). Papildomai straipsnyje yra dokumentuotos iki šiol neaprašytos rūšies iš Peru minos ant Polylepis racemosa lapų.

Raktažodžiai: Polylepis, Nepticulidae, Stigmella Schrank, naujos rūšys, minos ant lapų, Peru, Ekvadoras 